\title{
Ethical Issues of Globalizing Liberal Education: The Case of Japan
}

\author{
Christian Etzrodt \\ School of Human Sciences, Osaka University, Osaka, Japan \\ Email: etzrodtc@hotmail.com
}

How to cite this paper: Etzrodt, C. (2020). Ethical Issues of Globalizing Liberal Education: The Case of Japan. Creative Education, 11,1-15.

https://doi.org/10.4236/ce.2020.111001

Received: November 14, 2019

Accepted: January 5, 2020

Published: January 8, 2020

Copyright $\odot 2020$ by author(s) and Scientific Research Publishing Inc. This work is licensed under the Creative Commons Attribution International License (CC BY 4.0).

http://creativecommons.org/licenses/by/4.0/

\section{(c) (i) Open Access}

\begin{abstract}
Is it ethically justifiable to teach liberal education in non-Western countries, which might have a negative impact on the career of those programs' graduates, because they could be regarded as troublemakers, who destroy their own culture? In this paper, I will show that a fundamental value conflict exists between liberal education with its emphasis on autonomy and Japanese culture with its emphasis on harmony. But if this is the case, is the application of liberal education in Japan not cultural imperialism? I will argue that the moral dilemma can be dissolved by infusing Japanese area studies throughout the curriculum of a liberal arts program with its emphasis on the Western tradition. Such an integration would not privilege any kind of knowledge, and would give students real choices about what kind of values are better for their life and their society.
\end{abstract}

\section{Keywords}

Sociology of Education, Liberal Education, Japanese Education, Globalization of Education, Japanese Area Studies

\section{Introduction}

Liberal education is distinctively American (Koblik, 2000: p. 16). Most of the tertiary educational frameworks in other countries focus on specialized and career-focused programs. However, we can observe "a small but important international trend" in the last 20 years to export the idea of liberal education to the rest of the world (Godwin, 2017: p. 88f.). In 2013, 183 liberal education programs existed outside of the United States in 58 countries (Godwin, 2017: p. 89). The largest numbers of liberal arts programs were created in Canada, India, the United Kingdom, and Japan (Godwin, 2017: p. 90). To import a distinctively American education model to Canada and the United Kingdom is probably not 
such a big challenge, considering that those cultures are relatively close to the American culture(s). However, the transfer of liberal education to non-Western countries like India and Japan is a completely different thing. In this paper, I am interested to explore value conflicts between liberal education and non-Western cultures (in this case Japanese culture) and the moral dilemmas, which Westerners, who teach in non-Western countries liberal arts, are facing.

I will first argue that the core value of American liberal education is autonomy, whereas the core value of Japanese culture is harmony. I will shortly introduce how Japanese mass education is socializing Japanese to value harmony highly, before I will describe the history of "liberal education" in Japan. My argument is that although Japan has a long history of "liberal education", autonomy was never a central value in this indigenized version of "liberal education". Out of the different values in American liberal education and Japanese culture, I develop a moral dilemma, which arises in the application of an American-style liberal arts program in Japan. And finally, I offer a solution to this moral dilemma by proposing a curriculum that infuses comparative area studies throughout the different subject areas.

\section{American Liberal Education and Autonomy}

It is not an easy task to define the core value of liberal education, because the formative consensus about the ethical foundation of the American liberal arts colleges has disappeared (Gomes, 2000: p. 103). Most private liberal arts colleges were founded by Christians and many of their faculty were clergymen until the late 19th century (Yamashita, 2015: p. 24f.). However, many of these colleges have given up their commitment to their original Christian identity (Sheridan, 1998: p. 25), and turned into secular institutions (Gomes, 2000: p. 103). As a result, some commenters have questioned whether such a secularized liberal education is still capable of "addressing the question of values" (Gomes, 2000: p. 107; cf. Glyer/Weeks, 1998: p. 20; Terrell, 2009: p. 7). But even if not all American liberal arts colleges are teaching their students specific (Christian) values anymore, we do not necessarily need to conclude that modern liberal education has no core value at all.

Many liberal arts colleges would probably agree that liberal education has the aim to support students to find an answer to the central questions of their existence (e.g. Who am I? What ought I do with my life? What is true? What is good? What is beautiful? [Glyer/Weeks, 1998: p. 13f.; Roche, 2010: p. 148]), to liberate them from the "bondage of habit and custom" (Pascarella et al., 2005: p. 3 ), to recenter them in order to encourage them to seek their own pathways (Nussbaum, 2015: p. 80), and to help the them to develop their independent mind (Nussbaum, 2010: p. 473; cf. Chung, 2009: p. 4). Therefore, we could identify autonomy as the key value of liberal education. In this sense, the central difference between the American liberal arts colleges with a Christian identity and those with a secularized identity seems to be that the Christian institutions hope that their students find a faith-based answer to those central questions, whereas 
in secularized institutions the individual development without a specific set of Christian values is emphasized.

These religious institutions share a common goal with their secular counterparts: developing well-educated, critical thinkers who can function effectively in a democracy. For the Christian institution, however, this social goal is ultimately subservient to the goal of preparing Christians for service to Christ and the world. (Sheridan, 1998: p. 26)

However, to some degree also the value of autonomy can be regarded as a Christian or better Protestant value. The translation of the Latin Bible into living languages and the elimination of the priest as the intermediary between the believer and God during the Reformation created the opportunity for the Protestants to interpret the Bible in their own ways. This development let to a stronger emphasis on the individual conscience and the individual reasoning against traditional doctrines of the Catholic Church (Taylor, 2010: p. 434). This again had a profound influence of the Enlightenment and the development of the natural and social sciences. Empiricism became the driving force behind the discoveries of the seventeenth century in the natural sciences. And social contract theory became a tool to criticize the traditional social order (Taylor, 2010: p. 435).

Autonomy as the core value of liberal education is supplemented by the idea of the "whole person" (Conrad/Wyer, 1982; Boyer, 1987: p. 177; Hawkins, 2000; Lang, 2000). It is not only the aim of liberal education to teach students to understand themselves "but also the foundations of a democratic society and the responsibility of citizenship" (Pascarella et al., 2005: p. 3; cf. Roche, 2010: p. 149). In this sense, autonomy should not be equated with the self-interested individualism of the homo economicus. Another aspect of the "whole person"-idea is the rejection of a limited vocational education. Instead liberal education encourages the development of broad interdisciplinary knowledge and - what is more important - the ability to actively find connections between the different subject areas (Pring, 1993: p. 54; Chung, 2009: p. 4, 25; cf. Tristam, 1952: p. 79, 82).

And finally, the value of autonomy is closely related to another core competency of liberal education: critical thinking (Roche, 2010: p. 148). Critical thinking is the ability to critique or to evaluate statements from others and from oneself, instead of simply accepting them. Obviously, this ability requires the development of an autonomous mind in order to be able to challenge habitual/traditional ways of thinking as well as the statements of authorities.

\section{Japanese Culture and Harmony}

On the other hand, the core value of traditional Japanese culture is often described as harmony, or in Japanese, wa (Clammer, 1995: p. 102; Nakane, 1984: p. 52; De Mente, 2004: p. 304f.; 2005: p. 202f.; cf. Nisbett, 2003: p. 51). It was argued that harmony is the central value of the Japanese management system (Odaka, 1981: pp. 34-43), the managerial welfarism (Hazama, 1981), and the organization of agricultural communities (Gotō, 1983). The principle harmony 
regulates interactions by demanding "that all parties avoid bluntness and confrontations, that points, particularly in sensitive matters, be made indirectly, in such a way that one's position becomes known gradually, amorphously" (De Mente, 2005: p. 202; cf. Befu, 2001: p. 22). To be in harmony with the group implies furthermore that the group members are more concerned about the group goals than their personal goals (Clammer, 1995: p. 102). Consequently, individuals are rarely regarded as responsible for the success or the failure of the group (Nisbett, 2003: p. 48f.; De Mente, 2005: p. 203).

Harmony is a relational concept in contrast to the individualistic concept of autonomy. Unlike Westerners Japanese develop much closer connections to their in-group than to their out-groups (Nisbett, 2003: p. 51). Because of this weakened relationship to out-groups the concept of harmony does not eliminate conflicts in Japanese culture. It reduces the conflicts in the core in-groups, but not necessarily between different groups or factions in a large organization (Nakane, 1984: p. 10, 90f.). Of course, Japanese history is full of ideological attempts to define the whole of Japan as an in-group and therefore to eliminate conflicts entirely in order to preserve the power of the elites (Gluck, 1985: p. 38, 59, 177f., 276; Nemoto, 1999: p. 11f.). But the fact that the concept of harmony was misused in ideological discourses does not justify giving up the concept for the description of personal relationships and interactions in Japanese culture.

Leading Japanese intellectuals of the past were rejecting the idea of a "person". Among the first who challenged this concept was Watsuji Tetsurō (1889-1960). After his study of philosophy at the Tokyo University Watsuji translated several works of Søren Kierkegaard and Friedrich Nietzsche into Japanese. But he soon turned away from this individualistic Western philosophy under the influence of Nitobe's book on Bushido, The Soul of Japan (Kodera, 1987: p. 6). Watsuji criticized Western philosophers for their focus on the concept of time-an individualistic concept-and their neglect of the concept of space-a relational concept. He advocated a negation of the negation (the first negation rejects the group, whereas the second negation rejects the individual), which would lead to a "selfless" morality "by abandoning one's individual independence from others" (Carter/McCarthy, 2014). And the state would be the only place where the selfishness of the individuals can be overcome in order to create an absolute whole (Bellah, 2003: p. 123). During World War II Watsuji (1944) compared in his The Way of the Subject in Japan the following two principles: 1) "die happily for the sake of one's lord"; and 2) "do not die until the enemy is defeated." For Watsuji the first principle still contains too much selfishness, because it would emphasize one's self-sacrifice, whereas only the second principle would truly imply a negation of the negation (Bellah, 2003: p. 121).

Watsuji's ideas had a strong impact on what is usually called the nihonjinron. The nihonjinron is a group of theories publicized from the 1960s to the early 80 s, which tried to answer what characteristic of Japanese culture was responsible for the rapid industrialization of the only non-Western developed country at that time. Among the more reasonable theories is Nakane Chie's The Discovery 
of the Japanese Social Structure (1964) in which she compared Japan with India. She stated that relationships in Japan are organized around the place (for example, a Japanese would describe him-/herself as a member of the Mitsubishi company, but not as an engineer) - she called this a vertical organization with strong superior-subordinate relationships equivalent to the mother-child relationship -, whereas in India the focus is on the qualification, which she called a horizontal organization with strong peer-group relationships (Aoki, 1996: pp. 62-67). Interesting is that her classification system is based on the characteristics of relationships and not on the characteristics of individual actors.

Another relevant work was Kimura Bin's Between Person and Person (1972). He started with the analysis of the Japanese word for self jibun. This word consists of two kanji (Chinese signs). The first kanjiji can be translated as "self", whereas the second kanji bun means "part". Kimura concluded out of this that Japanese perceive their self always as a part of a variable group in contrast to the "unchangeable singular I" in the West (Aoki, 1996: pp. 75-77). Hamaguchi Eshun further developed this idea. He claimed in Japan, the Society of Contextualism (1982) that the base of the Japanese's identity is not in the individual Japanese "but in the context of the relationship with others" (Hamaguchi, 1996: p. 344). Therefore, he describes the "relatum" rather than the "individuum" as the configuring element of society (Hamaguchi, 1996: p. 341).

Watsuji, Nakane, Kimura, and Hamaguchi have in common that they do not regard the idea of a "person" as a relevant concept. And as a result, the idea of an autonomous person would not make much sense for them either. Furthermore, critical thinking, Western logic, and debate are not very well developed in Japanese culture, because discussions could threaten the harmony in the group (Nisbett, 2003: p. 73; Itasaka, 1978: p. 106; Hioki, 1990: p. 645; De Mente, 2005: p. 37f.; cf. McVeigh, 2002: p. 13).

Unfortunately, no empirical study exists which has tried to measure the importance of autonomy in Japan in comparison to other countries. The studies of Hofstede (2001), Trompenaars and Hampden-Turner (1998), and the GLOBE study (House et al., 2004) with their examination of the collectivism-individualism dichotomy are the closest empirical results available. The results are summarized in Table 1. All three studies show that Japanese culture is much more collectivistic than Western cultures. And although the concepts of collectivism and harmony are not identical, they are close enough to regard those empirical results as supportive evidence that Japanese culture values harmony much more highly than autonomy.

\section{Japanese Mass Education and Harmony}

Japanese are not determined by birth to prefer harmony rather than autonomy. They are socialized to value harmony very highly. An important role in this process plays the Japanese primary and secondary education system. Conformity and uniformity are enforced in Japanese schools through school uniforms (Nemoto, 1999: p. 75), group activities (Hendry, 1986: p. 170; Rohlen, 1989: p. 23; 
Table 1. Collectivism and individualism in 7 countries ${ }^{*}$ indicates the most collective country).

\begin{tabular}{ccccccc}
\hline \multirow{2}{*}{ Country } & Hofstede $^{\mathrm{a}}$ & \multicolumn{2}{c}{ GLOBE $^{\mathrm{b}}$} & \multicolumn{3}{c}{ Trompenaars and Hampden-Turner } \\
\cline { 2 - 6 } & & Institutional & In-group & Case A & Case B & Case C \\
\hline USA & 91 & 4.20 & 4.25 & $69 \%$ & $72 \%$ & $54 \%$ \\
UK & 89 & 4.27 & 4.08 & $61 \%$ & $70 \%$ & $48 \%$ \\
Australia & 90 & 4.29 & 4.17 & $63 \%$ & $64 \%$ & $58 \%$ \\
Netherlands & 80 & 4.46 & 3.70 & $65 \%$ & $70 \%$ & $43 \%$ \\
Germany & 67 & 3.79 & 4.02 & $53 \%$ & $62 \%$ & $36 \%$ \\
Japan & 46 & 5.19 & 4.63 & $39 \%^{*}$ & $43 \% *$ & $32 \%{ }^{*}$ \\
South Korea & $18^{\star}$ & $5.20^{*}$ & $5.54^{*}$ & - & $66 \%$ & $41 \%$ \\
\hline
\end{tabular}

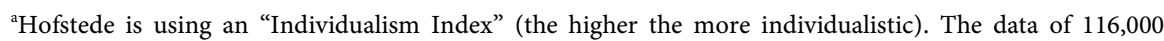
people was mostly collected within subsidiaries of IBM in 72 countries around 1968 and 1972 (Hofstede

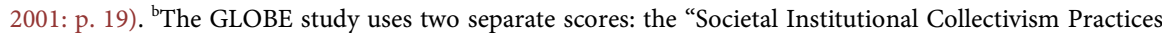
Score" and the "Societal In-Group Collectivism Practices Score". The data of 17,300 managers was collected in 951 organizations from 62 countries between 1994 and 1997 (House et al. 2004: p. 15, 22). 'Trompenaars and Hampden-Turner were providing cases with different options. Case A gives the percentage of people who opted for individual freedom. Case B and C give the percentage of people who preferred the option in which individual credit was received. The data comes from 30,000 managers of multinational corporations from 55 countries collected over the period of 15 years (Trompenaars/Hampden-Turner 1998: p. 1, 252). Source: Hofstede 2001: p. 215; House et al. 2004: p. 468f.; Trompenaars/Hampden-Turner 1998: p. 52, $55,57$.

Lewis, 1989; 1995: pp. 74-100; Nemoto, 1999: p. 47f.; Tsuneyoshi, 2001: pp. 24-34; Cave, 2007: p. 34), moral education (Nemoto, 1999: p. 23), grading the students' cooperative attitude (Yoneyama, 1999: pp. 10-12), standardization of everyday activities as for example greetings or cleaning (Hendry, 1986: p. 134-141; Peak, 1989: p. 115-116; Rohlen, 1989: p. 26; Tsuneyoshi, 1994: p. 120-128, Cave, 2007: p. 35), and rules for the behavior outside of the school (Yoder, 2004: p. 45). Also, the widespread phenomenon of bullying or ijime at Japanese schools can be regarded as a result of this push towards conformity (Fukuzawa, 1994: p. 79, 83; Yoneyama, 1999: p. 168; Yoder, 2004: p. 45). Instead of developing their independent mind, Japanese school kids are expected to copy and to memorize what teachers are telling them. "Tests examine factual knowledge rather than analytical abilities" (Nemoto, 1999: p. 44). And teachers try to discourage the students to ask questions, because they regard them as a challenge to their authority (Nemoto, 1999: p. 52, 215f.).

This focus in the socialization process on harmony was not even challenged by recent educational reforms that advocated additionally to the traditional values individual, creative, and independent thinking (Cave, 2007: p. 18). Especially critics from the Left pointed out that the term "individuality" as the government used it did not mean individuality, but implied a spread of tracking in and the destruction of the Japanese egalitarian education system (Hamabayashi, 1987: p. 24f.; Fujita, 2000: p. 54; Cave, 2007: p. 24). Authorized textbooks actually "made limited attempts to encourage the development of independence, autonomy, and individuality" (Cave, 2007: p. 108). 


\section{Japanese "Liberal Education" without Autonomy}

However, although the description of Japanese mass education gives the impression that the idea of liberal education was entirely marginalized in Japan. This was actually not the case. Japan has in fact a long tradition in liberal education. The idea of liberal education came from Germany to Meiji Japan in the concept of Bildung or character building of the full self. This concept became the founding principle of the higher schools (Sakuma, 2015: p. 6). The higher schools were elite residential schools, which existed from 1886 to 1950 and enrolled less than $1 \%$ of the male population between the ages of sixteen and nineteen (Sakuma, 2015: p. 12 n. 26). Mori Arinori, Japan's first minister of education, established the higher schools in order to socialize a nationalistic elite, which had a place at the prestigious Imperial Universities guaranteed, and which were recruited into elite government jobs (Roden, 1980: p. 20; Sakuma, 2015: p. 16). The first President of the First Higher School, Kinoshita Hiroji, "administered a self-governing system of the dorms," in order to support the students "to cultivate 'status and responsibility' as elites who work for the nation” (Sakuma, 2015: p. 16). Kinoshita made the following statement in his speech to the students, which shows that autonomy given to the students has not the aim to foster individual autonomy, but the autonomy of a group of peers:

[F]or you students to lead a moral life by cultivating your spirit correctly, while living in a society that reeks with bad manners and obscenity, is a formidable task. I understand your distressing situation, but I believe it essential that you be resolute [...] You students must acknowledge your "status and responsibility (chii to sekinin)" and arouse the spirit of self-government [...] This will depend upon the way you interact as friends striving to admonish each other and polish each other's character. (Ichikō Dōsōkai, 1994: p. 25; translated by Roden; emphases added)

The students of the higher schools were not given the freedom in order to answer the central questions of their existence individually. They were given the freedom in order for them to set up a system of peer pressure, which not only promoted excellence but also the idea that the collectivity is more important than any individual. The most shameful thing was not academic failure, but the criticism of the peers (Kitada, 2013: p. 84f.). Existential questions were asked, but they were discussed and answered by the group of peers (Takeuchi, 1999: p. 310-313). Consequently, graduates of the higher schools emphasized that they have to "serve the nation" (Asano, 1995: p. 301; Kitada, 2013: p. 40) and to "sacrifice themselves for others" (Nakano, 1999: p. 509). This actually sounds much more like an education based on bushido rather than liberal education.

The higher schools were abolished in 1950 during the educational reforms of the American occupation (1945-1952). The Supreme Commander of the Allied Powers (SCAP) saw in the higher schools a contributor to the development of totalitarian state in Japan (Hata, 2003: p. 216-220; Sakuma, 2015: p. 19), and therefore regarded them as an obstacle for the transformation of Japan into a 
democratic society. In order to achieve this transformation, the SCAP introduced furthermore general education-"a concept that was developed at institutions such as the University of Chicago and Harvard University as a way to construct a holistic undergraduate curriculum to continue the 'liberal and humane tradition' in the mid-20th century" (Sakuma, 2015: p. 34)—into the Japanese higher education system (Sakuma, 2015: p. 6). But the SCAP left the implementation of the general education into the Japanese higher education system to the Japanese officials (Trainor, 1983: p. 65; Sakuma, 2015: p. 35). The Japanese officials, however, were not strong supporters of this idea as the statement of Sasaki Shigeo, the chair of the Committee on University Establishment, shows: "We have taught general education in high schools. What's the point of teaching it in universities?" (Yoshida, 2013: p. 51; translated by Sakuma, 2015: p. 36). The result was that the Japanese officials interpreted general education just as a study of a wide range of subjects (Sakuma, 2015: p. 6), and the University Establishment Standards of 1947 required universities to offer courses in the humanities, social sciences and sciences. Most of the universities fulfilled this requirement by offering general education courses in the first two years and specialized courses in the last two years (Sakuma, 2015: p. 36).

The implementation of the general education in the universities was also not supported by the faculty members, who favored specialized training (Sakuma, 2015: p. 36). Furthermore, the general education instructors were discriminated by the university administrators. They received lower pay (Yoshida, 2013: p. 56) and had not the same rights to teach upper-level courses as the other faculty members. Therefore, not many faculty members were willing to teach the general education courses, and since the number of students increased dramatically after the war, the result was a student-to-faculty ratio of 300 to 1 in the general education courses (Tsuchimochi, 2006: p. 42). Obviously, under those conditions it is nearly impossible to create a student-centered learning environment with interactive classes, which are typical for American liberal arts colleges. It is not a surprise that the Japanese students did not take the general education lectures seriously (Sakuma, 2015: p. 37). Konuma Michiji, professor at Keio University, described those general education programs as "wide and shallow" (Keiō Gijuku Daigaku Kyōyō Kyōiku Sentā, 2002).

The Japanese Ministry of Education deregulated the University Establishment Standards in 1991 and abolished the requirements for general education courses. Most of the universities used this new freedom in the design of their curriculum to increase the number of specialized courses and the liberal education disappeared in Japan (Yoshida, 2013: p. 73-115; Sakuma, 2015: p. 2), until in the 2000s new liberal arts programs were established (Sakuma, 2015: p. 30).

\section{Ethical Issues of Applying American Liberal Education in Japan}

It seems that the dominant moral value of harmony (which emphasizes the 
group) in Japanese culture stands in a sharp contrast to the core value of autonomy (which emphasizes the individual) in American liberal education. This is not a problem as long as only an indigenized form of "liberal education" is applied in Japan. However, since 2004, several new 4-year liberal arts programs were created in Japan, which were designed in the tradition of American liberal education. Akita International University and the International College of Liberal Arts at Yamanashi Gakuin University are good examples for those programs. Both colleges were newly established and not the result of a restructuring of existing departments. Additionally, both have a direct connection to the failed branch campuses of American universities, which were established in the 1980s and 1990s (Etzrodt et al., 2016: p. 70-76). I have taught in these two liberal arts programs sociology, and I always faced an ethical problem of justifying an education that focuses on the development of the students' individual autonomy and critical thinking skills. The problem is that this type of education, if internalized, might have a negative impact on the student's life after graduation. Young people in Japan might want to change, but most of the companies in Japan are still very conservative, and will regard an autonomous and critical individual as a troublemaker, who cannot read the air.

The result is a moral dilemma. On the one hand, I want the students to become autonomous individuals, so that they can make their own choices. But in order to give them a choice, I have to challenge their taken-for-granted beliefs and value system, which in turn might have a "subversive and even destructive impact on Japanese culture" (Etzrodt et al., 2016: p. 80). This leads furthermore to the question, whether I, as a "Westerner," have a right to destroy a non-Western culture? Is this not cultural imperialism? As a matter of fact, university administrators of liberal arts programs in the Middle East have referred to Western cultural imperialism as a justification for punishing faculty members, who have crossed the line by exercising critical thinking (Noori, 2017: p. 147). Of course, I am not so important that my teaching alone would have an impact on Japanese culture nor does the Japanese government care about what I am saying in my classroom. But I am also not the only one, who is teaching in these new American-style liberal arts programs in Japan.

Supporters of American liberal education might reply that the value of autonomy is a cosmopolitan and universal value. Are the human rights not clearly protecting the autonomy of the individual against the state or the group? Unfortunately, this argument is flawed, since the human rights are rather British than universal, and the value of autonomy is not very important in non-Protestant cultures. Furthermore, considering that most of the American liberal arts colleges are still following the Western tradition (Flannery/Newstad, 1998: p. 23; Stanley, 2000: p. 273), any attempt to justify the application of liberal education in non-Western countries based on claims of universalism must appear ethnocentric (Stanley, 2000: p. 273; cf. Tan, 2017: p. 135). The moral dilemma cannot be dissolved in this way.

Charlene Tan (2017) approaches this moral dilemma from a different point of 
view. She describes a very similar conflict between autonomy and adversarial critical thinking on the one hand and harmony and cooperative critical thinking on the other at Yale-NUS College in Singapore. The application of a liberal education in an authoritarian country and the cooperation with the National University of Singapore forced Yale University to compromise and to deviate from its 1975 University Policy on Freedom of Expression. Yale-NUS College rejects now the adversarial critical thinking and promotes cooperative "critical" thinking (Tan, 2017: p. 134). This type of indigenized "liberal education" might be suitable for the Asian context (Tan, 2017: p. 135), but it fails to do one important thing. It fails to provide a choice. In order to give students from Singapore or other Asian cultures with Confucian background a choice, it would be necessary to teach them adversarial critical thinking. They cannot choose what they do not know. The moral dilemma can also not be dissolved in this way.

\section{A Comparative Area Studies Curriculum}

Another approach of addressing the moral dilemma of applying liberal education in non-Western cultures can be derived out of the idea of area studies, especially Asian studies, in liberal arts colleges. Area studies do not aim to produce general truths but focus on multiple particularisms (Stanley, 2000: p. 274). They try to understand other cultures and to compare them with their own culture. In the debate about the future of liberal education in the United States, Asian studies play an important role. It has been argued that the integration of Asian studies into the Western-centric curriculum of liberal arts colleges would broaden the students' horizon and allow them to see the world from different perspectives (Barnett/Symons, 2015: p. 11; Coburn, 2015: p. 14f.). Especially Asian studies are suitable for an inclusion into American liberal arts colleges, because of "the unparalleled richness of the subject matter" of the regional high cultures (Coburn, 2015: p. 10), which created religions, art, and literature similar to the achievements of the West (Stanley, 2000: p. 275).

This area studies approach provides now conveniently a solution to the moral dilemma. If a liberal education program in Japan is set up as a comparative area studies program, which compares the standard Western tradition of American liberal arts colleges with the Japanese tradition, then the students could choose between the different traditions without being manipulated to accept a specific set of values. Such a program would still have the aim to support the students to find their own answers to the central questions of their existence. But since the values of autonomy and harmony are presented equally, the students could come (autonomously) to the conclusion that harmony is more suitable for their life or their society (Etzrodt et al., 2016: p. 82).

This argument leads to the next question, whether the Japan area studies should be established as an independent program in a liberal arts curriculum, or whether it should be infused throughout the curriculum (Coburn, 2015: p. 17). The answer to this question is in this particular context easy. It has to be infused 
into all the different subject areas (e.g. literature, art, philosophy, economics, and sociology) throughout the curriculum in order to guarantee that every student will be forced to look at problems in his/her subject area from different cultural perspectives. This should be done coherent and affect all courses in the humanities and the social sciences. For example, courses in Art should include not only the History of Western Art, but also the History of Japanese Art and an upper-level course in Comparative Art Aesthetics (cf. Etzrodt et al., 2016: p. 82). This principle could be even applied to some degree in architecture or engineering. However, here the focus would have to shift to the question of whether designs should address individual needs (autonomy) or the needs of the society (harmony).

This kind of intercultural study experience can be further intensified by two factors: diversity of the student body and study abroad. Ideally, the number of students from the home country (in this case Japanese) should be around 50\% of the student body. Diversity guarantees that students are not only experiencing other cultures through the content of the curriculum, but also in class discussions and extra-curricular activities. Diversity can even go beyond the design of the curriculum with its focus on two cultures (in this case the "Western" and the Japanese tradition), if the students have many different nationalities. For example, African students will add their cultural point of view to class discussions, and therefore allow other students to learn something about Africa, although the curriculum itself did not provide any courses related to Africa. These multicultural experiences can be enhanced, if the program is embedded into a residential campus, and the allocation of the students to the different dormitories is done consciously in order to mix the student population.

Internationalization at home is a very effective strategy to provide students with experiences, which will help them to make important choices about their lives. But internationalization at home cannot replace the experience of studying abroad, because even such an international liberal arts program in Japan would be still a very protected and guided experience for the students. However, students have to learn to take responsibility for their own lives, and they have to learn to overcome challenges without the help of their ethnic community.

Study abroad, more than other academic experiences, presents participants with "total" educational experiences. It involves the full person and indeed springs from the play of embodied subjectivities. It challenges students to perform new roles in new languages. In doing this, it reveals dimensions of the human experience-the tacit assumptions of everyday life-in ways not accessible in single cultural settings. (Nussbaum, 2015: p. 76)

Sometimes this radical experience will lead to an appreciation of freedom in individualistic societies, and sometimes it will convince them that their harmonious Japanese society is worth to preserve. I have often asked my Japanese students after they returned from study abroad whether they were appreciating their own culture now more or less. Half of these students answered that they wanted to change Japan after their experiences abroad, whereas the other half 
wanted to conserve Japanese culture. But what was interesting that nearly all of the students had an opinion, although they had no clear attitude towards their own culture before study abroad.

\section{Conclusion}

Does the application of liberal education in non-Western cultures, which emphasize harmony over autonomy, necessarily lead to cultural imperialism? I do not think so. I believe that it is possible to establish liberal arts programs in non-Western countries in a way, which avoids the brainwashing of students. But in order to create a multicultural learning environment, which provides both the knowledge about different cultural traditions as well as the autonomous space for the students to choose between them, the curriculum has to be designed carefully. If this is done well, the students (Japanese and non-Japanese) "would receive a very solid foundation for answering the central questions of their existence. They could make an informed decision about which values they want to pursue in their life" (Etzrodt et al., 2016: p. 82). Such a liberal arts program would not manipulate students to accept American values and an American life-style, although liberal education is distinctively American.

\section{Conflicts of Interest}

The author declares no conflicts of interest regarding the publication of this paper.

\section{References}

Aoki, T. (1996). Der Japandiskurs im historischen Wandel. München: Iudicium.

Asano, T. (1995). Okaniagarichi. Tokyo: IchikōDōsōkai.

Barnett, S. W., \& Symons, V. J. (2015). Prologue. In S. W. Barnett, \& V. J. Symons (Eds.), Asia in the Undergraduate Curriculum: A Case for Asian Studies in Liberal Arts Education (pp. 11-13). London: Routledge.

Befu, H. (2001). Hegemony of Homogeneity. Melbourne: Trans Pacific Press.

Bellah, R. N. (2003). Imagining Japan. Berkeley, CA: University of California Press.

Boyer, E. L. (1987). College: The Undergraduate Experience in America. New York: Harper and Row.

Carter, R., \& McCarthy, E. (2014). Watsuji Tetsurō. In E. N. Zalta (Ed.), The Stanford Encyclopedia of Philosophy.

http://plato.stanford.edu/archives/win2014/entries/watsuji-tetsuro/

Cave, P. (2007). Primary School in Japan. London: Routledge. https://doi.org/10.4324/9780203935811

Chung, J. (2009). Liberal Arts Education in the United States of America. Saarbrücken: VDM Verlag.

Clammer, J. (1995). Difference and Modernity: Social Theory and Contemporary Japanese Society. London: Routledge.

Coburn, T. B. (2015). Asia and the Undergraduate Curriculum. In S. W. Barnett, \& V. J. Symons (Eds.), Asia in the Undergraduate Curriculum: A Case for Asian Studies in 
Liberal Arts Education (pp. 3-22). London: Routledge.

Conrad, C. F., \& Wyer, J. C. (1982). Seven Trends in Liberal Learning. Washington DC: Association of Governing Boards of Universities and Colleges.

De Mente, B. L. (2004). Japan's Cultural Code Words. Tokyo: Tuttle.

De Mente, B. L. (2005). Japan Unmasked: The Character and Culture of the Japanese. Tokyo: Tuttle.

Etzrodt, C., Hrebenar, R., Lacktorin, M., \& Nilson, D. (2016). The Application of a Western-Style Liberal Arts Education Model in a Non-Western Environment: The Case of Japan. International Journal of Chinese Education, 5, 65-84. https://doi.org/10.1163/22125868-12340061

Flannery, C., \& Newstad, R. W. (1998). The Classical Liberal Arts Tradition. In D. Glyer, \& D. L. Weeks (Eds.), The Liberal Arts in Higher Education (pp. 3-23). Lanham: University Press of America.

Fujita, H. (2000). Education Reform and Education Politics in Japan. The American Sociologist, 31, 42-57. https://doi.org/10.1007/s12108-000-1033-9

Fukuzawa, R. E. (1994). The Path to Adulthood According to Japanese Middle Schools. Journal of Japanese Studies, 20, 61-86. https://doi.org/10.2307/132784

Gluck, C. (1985). Japan's Modern Myths: Ideology in the Late Meiji Period. Princeton, NJ: Princeton University Press.

Glyer, D., \& Weeks, D. L. (1998). Liberal Education: Initiating the Conversation. In The Liberal Arts in Higher Education (pp. 9-29). Lanham, MD: University Press of America.

Godwin, K. A. (2017). Précis of a Global Liberal Education Phenomenon: The Empirical Story. In P. Marber, \& D. Araya (Eds.), The Evolution of Liberal Arts in the Global Age (pp. 87-105). New York: Routledge. https://doi.org/10.4324/9781315645216-8

Gomes, P. J. (2000). Affirmation and Adaptation: Values and the Elite Residential College. In S. Koblik, \& S. R. Graubard (Eds.), Distinctively American: The Residential Liberal Arts College (pp. 101-119). New Brunswick: Transaction Publishers.

Gotō, T. (1983). Nihon-tekikeiei to bunka. Tokyo: Gakubunsha.

Hamabayashi, M. (1987). Sōkatsuhihan 'rinkyōshin'. Tokyo: Gakushu-no-tomo-sha.

Hamaguchi, E. (1982). Kanjinshugi no shakainihon. Tokyo: Tōyō Keizai Shimpōsha.

Hamaguchi, E. (1996). The Contextual Model in Japanese Studies. In J. Kreiner, \& H. D. Ölschleger (Eds.), Japanese Culture and Society (pp. 337-357). München: Iudicium.

Hata, I. (2003). Kyūseikōkōmonogatari. Tokyo: Risōsha.

Hawkins, H. (2000). The Making of the Liberal Arts College Identity. In S. Koblik, \& S. R. Graubard (Eds.), Distinctively American: The Residential Liberal Arts Colleges (pp. 1-25). New Brunswick: Transaction Publishers.

Hazama, H. (1981). Nihon no keiei. Tokyo: Nihon Keizai Shinbunsha.

Hendry, J. (1986). Becoming Japanese. Manchester: Manchester University Press.

Hioki, K. (1990). Normen und Werte. In H. Hammitzsch (Ed.), Japan-Handbuch (pp. 640-646). Stuttgart: Franz Steiner.

Hofstede, G. (2001). Culture's Consequences (2nd ed.). Thousand Oaks, CA: Sage.

House, R. J., Hanges, P. J., Javidan, M., Dorfman, P. W., \& Gupta, V. (2004). Culture, Leadership, and Organizations: The GLOBE Study of 62 Societies. Thousand Oaks, CA: Sage.

Ichikō Dōsōkai (1994). Daiichi kōtōgakkōjichiryōrokujyūnenshi. Tokyo: Ichikō Dōsōkai. 
Itasaka, G. (1978). Nihongo no hyōjō. Tokyo: Kōdansha.

Keiō Gijuku Daigaku Kyōyō Kyōiku Sentā (2002). Kaishokinenshinpojium. http://lib-arts.hc.keio.ac.jp/publication/uploadimages/pdf/1358155242.pdf

Kimura, B. (1972). Hito to hito to no aida: Seishinbyōrigakutekihihonron. Tokyo: Kōbundō.

Kitada, H. (2013). Kyuseikōkō shin no erīto no tsukurikata. Tokyo: Nihon Kōgyō Shinbunsha.

Koblik, S. (2000). Forword. In S. Koblik, \& S. R. Graubard (Eds.), Distinctively American: The Residential Liberal Arts College (pp. 15-16). New Brunswick: Transaction Publishers.

Kodera, J. T. (1987). The Romantic Humanism of Watsuji Tetsurō. Dialogue \& Alliance, 1, 4-11.

Lang, E. M. (2000). Distinctively American: The Liberal Arts College. In S. Koblik, \& S. R. Graubard (Eds.), Distinctively American: The Residential Liberal Arts Colleges (pp. 133-150). New Brunswick: Transaction Publishers.

Lewis, C. C. (1989). From Indulgence to Internationalization. Journal of Japanese Studies, 15, 139-157. https://doi.org/10.2307/132411

Lewis, C. C. (1995). Educating Hearts and Minds. Cambridge: Cambridge University Press.

McVeigh, B. J. (2002). Japanese Higher Education as Myth. Armonk, NY: M.E. Sharpe.

Nakane, C. (1964). Nihontekishakaikōzō no hakken. ChūoKōron, 5, 48-85.

Nakane, C. (1984). Japanese Society. Tokyo: Tuttle.

Nakano, H. (1999). Anotokinohitokoto. Tokyo: IchikōDōsōkai.

Nemoto, Y. (1999). The Japanese Education System. Parkland, FL: Universal Publishers.

Nisbett, R. E. (2003). The Geography of Thought. New York: Free Press.

Noori, N. (2017). Academic Freedom and the Liberal Arts in the Middle East: Can the US Model Be Replicated? In P. Marber, \& D. Araya (Eds.), The Evolution of Liberal Arts in the Global Age (pp. 141-149). New York: Routledge. https://doi.org/10.4324/9781315645216-11

Nussbaum, M. C. (2010). A Classical Defense of Reform in Liberal Education. In B. A. Kimball (Ed.), The Liberal Arts Tradition (pp. 471-480). Lanham, MD: University Press of America.

Nussbaum, S. P. (2015). Study Abroad in Asia. In S. W. Barnett, \& V. J. Symons (Eds.), Asia in the Undergraduate Curriculum: A Case for Asian Studies in Liberal Arts Education (pp. 76-97). London: Routledge.

Odaka, K. (1981). Sangyōshakaigakukōgi. Tokyo: Iwanami Shoten.

Pascarella, E. T., Wolniak, G. C., Seifert, T. A. D., Cruce, T. M., \& Blaich, C. F. (2005). Liberal Arts Colleges and Liberal Arts Education. ASHE Higher Education Report, 31, 7-146.

Peak, L. (1989). Learning to Become Part of the Group. Journal of Japanese Studies, 15, 93-123. https://doi.org/10.2307/132409

Pring, R. (1993). Liberal Education and Vocational Preparation. In R. Barrow, \& P. White (Eds.), Beyond Liberal Education (pp. 49-79). London: Routledge.

Roche, M. W. (2010). Why Choose the Liberal Arts? Notre Dame: University of Notre Dame Press.

Roden, D. (1980). Schooldays in Imperial Japan: A Study in the Culture of a Student Elite. 
Berkeley, CA: University of California Press.

Rohlen, T. P. (1989). Order in Japanese Society. Journal of Japanese Studies, 15, 5-40. https://doi.org/10.2307/132406

Sakuma, M. (2015). Reviving, Modifying, and Inventing: Liberal Arts Education in Japan's Lost Decades. Williamstown: Williams College.

Sheridan, D. A. (1998). Modern and Postmodern Challenges to Liberal Education. In D. Glyer, \& D. L. Weeks (Eds.), The Liberal Arts in Higher Education (pp. 25-45). Lanham, MD: University Press of America.

Stanley, P. W. (2000). At Home in Our World: The Place of International Studies in Liberal Arts Colleges. In S. Koblik, \& S. R. Graubard (Eds.), Distinctively American: The Residential Liberal Arts College (pp. 273-291). New Brunswick: Transaction Publishers.

Takeuchi, Y. (1999). Gakurekikizoku no eikō to zasetsu. Nihon no kindai (Vol. 12). Tokyo: ChūōKōronsha.

Tan, C. (2017). Thinking Critically about Liberal Arts Education: Yale-NUS College in Singapore. In P. Marber, \& D. Araya (Eds.), The Evolution of Liberal Arts in the Global Age (pp. 127-140). New York: Routledge. https://doi.org/10.4324/9781315645216-10

Taylor, H. (2010). Individualism and the Liberal Tradition. In B. A. Kimball (Ed.), The Liberal Arts Tradition (pp. 433-436). Lanham, MD: University Press of America.

Terrell, R. (2009). The Liberal Arts in the Twenty-First Century. New York: iUniverse.

Trainor, J. C. (1983). Educational Reform in Occupied Japan: Trainor's Memoir. Tokyo: Meiji University Press.

Tristam, H. (1952). The Idea of a Liberal Education: A Selection from the Works of Newman. London: George G. Harrap.

Trompenaars, F., \& Hampden-Turner, C. (1998). Riding the Waves of Culture: Understanding Cultural Diversity in Global Business (2nd ed.). New York: McGraw-Hill.

Tsuchimochi, G. H. (2006). Sengonihon no kōtōkyōikukaikakuseisaku. Tokyo: Tamagawa Daigaku Shuppanbu.

Tsuneyoshi, R. (1994). Small Groups in Japanese Elementary School Classrooms. Comparative Education, 30, 115-129. https://doi.org/10.1080/0305006940300204

Tsuneyoshi, R. (2001). The Japanese Model of Schooling. New York: Routledge Falmer.

Watsuji, T. (1944). Nihon no shindō. Tokyo: Chikuma Shobō.

Yamashita, S. H. (2015). Asian Studies at American Private Colleges, 1808-1990. In S. W. Barnett, \& V. J. Symons (Eds.), Asia in the Undergraduate Curriculum: A Case for Asian Studies in Liberal Arts Education (pp. 23-51). London: Routledge.

Yoder, R. S. (2004). Youth Deviance in Japan. Melbourne: Trans Pacific Press.

Yoneyama, S. (1999). The Japanese High School: Silence and Resistance. London: Routledge.

Yoshida, A. (2013). Daigaku to kyōyōkyōiku. Tokyo: Iwanami Shoten. 